
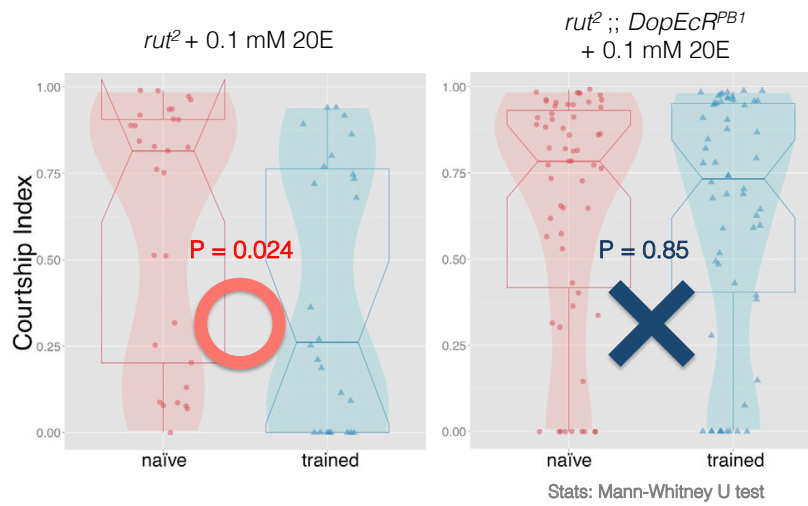

図3 rutabaga変異体の記憶異常は、エクダイソン／ DopEcRシグナルの活性化で回復する

左図：rut変異体の短期記憶異常はエクダイソン投与で回復 された。右図：rutとDopEcRの二重変異体ではエクダイソン の記憶回復の効果が消失する。参考文献2から表示形式を改変。

から、DopEcRはショウジョウバエの短期記憶に必要で あることが分かった。また、エクダイソン合成酵素の遺 伝子発現を RNAiにより抑制し、短期記憶異常が引き起 こされたハエはエクダイソン投与により記憶異常が回復 するが、さらにDopEcR遺伝子発現も抑制すると、エク ダイソンを投与しても記憶は回復しなかった。このこと は、DopEcRを介したエクダイソンシグナルが短期記憶 に重要であることを示している。

\section{エクダイソンシグナルと記憶遺伝子の遺伝的相互作用}

多くの動物種で cAMPは記憶形成において重要な細胞 内シグナル分子として知られている。ショウジョウバエ の rutabaga (rut) 遺伝子はcAMP合成酵素であるアデニ ル酸シクラーゼをコードする。このrut遺伝子変異体は 失恋記憶異常を示すが、驚くべき事にエクダイソン投与 によって記憶異常が回復することを発見した。そこで、 $r u t$ 遺伝子とDopEcR遺伝子の二重突然変異体の記憶につ いて調べた。この二重突然変異体は、短期記憶異常を示 すが先ほどのエクダイソン投与による記憶回復効果が見 られなくなっていた (図3)。つまり、rut遺伝子変異に よる cAMPの低下がエクダイソン/DopEcRシグナルの 活性化によって記憶が回復したと推測される。cAMP指

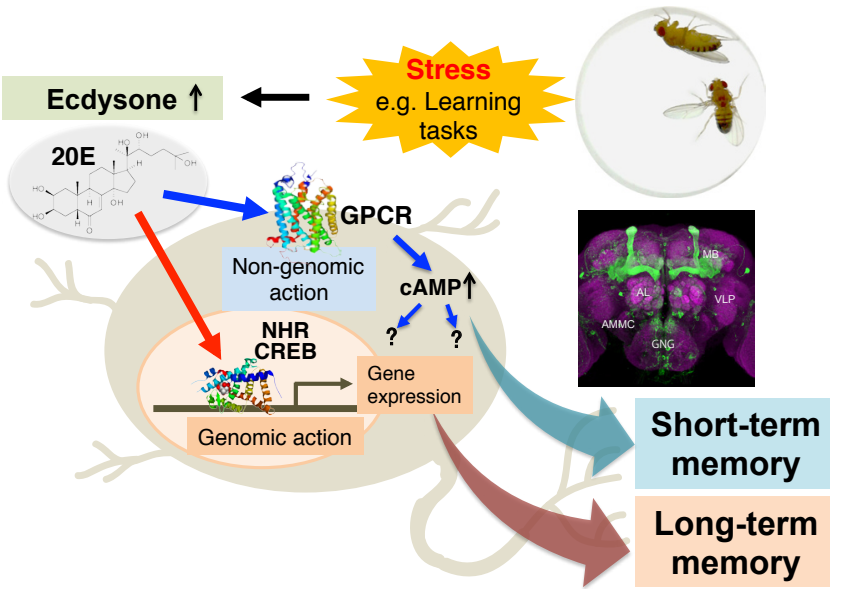

図4昆虫ステロイドホルモンの脳神経作用 これまで未知であった昆虫ステロイドホルモンの記憶への関与 が明らかになった。長期記憶と短期記憶で異なるシグナル経路 が示された。

示蛍光タンパク質を用いたイメージング解析により、エ クダイソン投与によって cAMPの合成がキノコ体で上昇 することが確認できた。また、キノコ体のDopEcR遺伝 子発現を抑制すると、エクダイソン投与による cAMP合 成が抑制された。これらのことから、エクダイソン／ DopEcRシグナルは、記憶に必須のcAMP合成酵素 rut と遺伝的な相互作用が示された。

\section{昆虫ステロイドホルモンの記憶学習制御機構}

昆虫ステロイドホルモンの脳神経制御の働きは、現象 そのものが不明であった。本研究により高度な脳神経機 能である記憶学習行動にエクダイソンが関与することが 明らかになったことで、昆虫をモデルとした実験系が適 用できる道が開けたのではないだろうか (図4)。昆虫ス テロイドホルモンの記憶学習制御機構は未だ多くが謎に 包まれている。この未開拓の分野にモデル生物としての 利点を生かしてどこまで切り込めるか楽しみである。

文献

1) Ishimoto $\mathrm{H}$ et al. Proc Natl Acad Sci USA, 106, 6381-6 (2009).

2) Ishimoto H et al. PLoS Genet, 9, e1003843 (2013).

\title{
植物のシステミックな窒素取り込み制御を担う 新しいペプチドリガンドー受容体ペア
}

松林 嘉克 (名古屋大学大学院理学研究科・生命理学専攻・細胞間シグナル研究グループ)

E-mail: matsu@bio.nagoya-u.ac.jp

\section{要約}

新しいペプチドホルモンの探索にはいくつかの方向性 があるが、一般的には特定の生命現象を深く解析する中 で偶然見つけられる場合が多い。しかし、我々はあえて 現象面ではなく分子側からのアプローチを試みてきた。
翻訳後修飾やプロセシングを経て短鎖ペプチドとして分 泌されるグループの前駆体ペプチド群には、アミノ酸配 列に独特の特徵がある。この特徵に基づいて候補ペプチ ド群を絞り込み、その機能を解析することで、最後に現 象やしくみの解明につなげようというアプローチである。 
シロイヌナズナ全ORFに対して行なった in silicoスクリ ーニングでは、比較的大きなファミリーが2つと、小さ いものが数個見出された。このアプローチにより見出さ れたもののひとつが、植物のシステミックな窒素取り込 み制御を担うぺプチドホルモン CEPである。

植物にとつて窒素は最も重要な無機栄養のひとつであ る。植物は地中から窒素を主に硝酸イオンとして吸収し ているが、自然界での硝酸イオンの地中分布は、極めて 不均一である。そのため、植物は根の一部が局所的な窒 素欠乏になった時に、その情報を他の根に伝え、相補的 に硝酸イオン取り込みを促進させるしくみを持っている。 しかし、systemic N-demand signalingと呼ばれるこの巧 妙なしくみの分子メカニズムは解明されていなかった。 我々は、根の一部が局所的な窒素欠乏を感知した時に生 産されるシグナルこそがCEPであり、それらが導管を 移行して地上部の受容体 CEPRに認識されることが引き 金となって、最終的に植物体全体に窒素欠乏の情報を伝 えていることを見出した。このシステミックな情報伝達 によって、別の根での硝酸イオン取り込みが増大し、局 所的な窒素不足が補填されているのである。この発見は、 変動する環境に対する植物の巧みな適応能力の一端を明 らかにするものである。

\section{CEPファミリーペプチドの同定}

近年、植物の形態形成や環境応答において、比較的短 い(数アミノ酸から数十アミノ酸残基) 分泌型ペプチド が重要な役割を果たすことが明らかになりつつある。こ

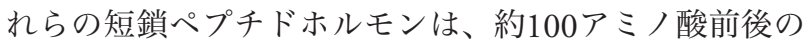
前駆体ペプチドのC末端付近が翻訳後修飾およびプロ セシングを受け、10～20アミノ酸の活性型ペプチドとし て切り出され分泌される(図1A)。筆者らのグループで は、既知の短鎖翻訳後修飾ペプチドホルモンの前駆体ペ プチドの構造的特徵 (分泌型シグナル配列を持っており、 C末端付近の成熟型ペプチド領域のみが進化の過程で選 択圧を受けるためにファミリー内で配列保存されており、 ジスルフィド結合をつくりうるシステイン残基を含ま ない、等) や植物界における保存性に基づき、シロイヌ

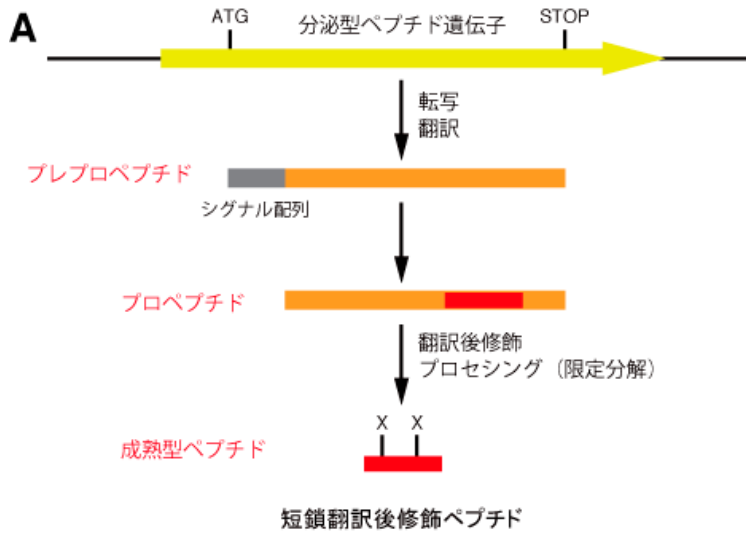

ナズナゲノムからいくつかの新規ペプチドホルモン候補 遺伝子群を抽出・解析してきた。そのひとつがCEP (Cterminally Encoded Peptide) ファミリーであり、シロイ ヌナズナには少なくとも11個の遺伝子が見出された (図 1B、C)。CEPの多くは根で特異的に発現がみられ、過 剩発現もしくは合成ぺプチドを培地に加えた場合では根 の生育が抑制されたことから、根の成長制御に関連する ペプチドであることが示唆された。しかしながら、CEP は高度な遺伝子重複のために完全な欠損株の作成は難し く、その機能解明は当初難航した。

\section{CEP 受容体の同定}

そこで著者らは、CEPを認識する受容体をまず同定 し、その欠損株の解析から CEPファミリーペプチドの 機能を明らかにすることを試みた。受容体候補としては、 短鎖ペプチドの受容体として機能する分子がいくつか含 まれるシロイヌナズナのロイシンリッチリピート型受容 体キナーゼ (LRR-RK) のサブファミリーXおよびXIの 約40種類に着目した。これらを個々にタバコ培養細胞 BY-2で過剩発現させ、膜画分を回収して、LRR-RK発 現ライブラリーとした。このライブラリーに対して、光 反応性 CEP1を用いたフォトアフィニティーラベルによ る網羅的結合実験を行なったところ、CEP1と直接結合 する2つのLRR-RKが見出された（図1D)。両者は、共に LRR型受容体キナーゼのサブファミリーXIに属し、こ れらの二重欠損変異体はCEP1に対して非感受性を示し た。よって、これら2つのLRR-RKがCEP受容体である と結論づけ、CEPR1およびCEPR2 と命名した。CEPR1 はCEP1だけでなく、CEP3やCEP5とも 結合したこと から、CEPファミリー共通の受容体であると考えられた。 CEPR1およびCEPR2の発現は植物体全体で観察された が、CEPR1は特に葉の維管束で高い発現レベルを示した。

\section{CEPは全身的な窒素要求シグナリングに関与する}

CEP受容体二重欠損変異体の表現型解析を行なった ところ、側根の伸長や、葉の黄化、植物体の矮小化など の形態変化がみられた。これらの表現型は、植物が窒素

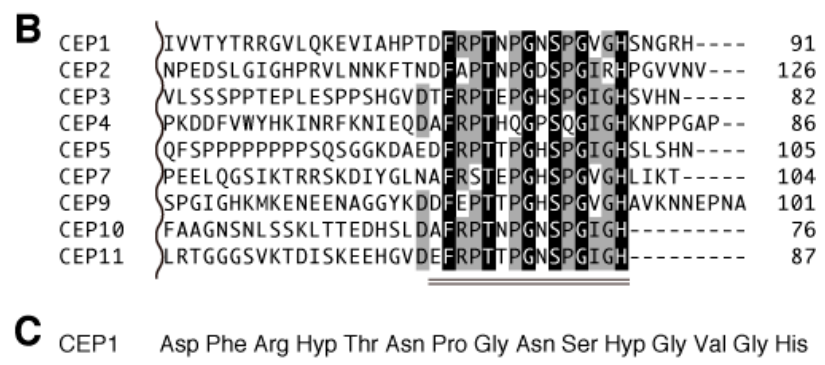

D $_{\text {CEPR1 }}$

CEPR2

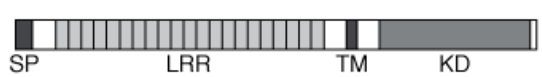

図1 ペプチドホルモンCEPおよび受容体CEPRの構造

(A) 短鎖翻訳後修飾ペプチドホルモンの典型的な生産経路。（B）代表的なCEPの前駆体ペプチド配列。C末端付近にのみ保存 配列があり、この領域が翻訳後修飾とプロセシングを経て活性のある成熟型ペプチドとなる。(C) CEP1の成熟型ペプチド構造。 (D) 受容体CEPRの構造。シグナルペプチド (SP)、ロイシンリッチリピート (LRR)、膜貫通領域 (TM)、キナーゼ領域 (KD)。 
A

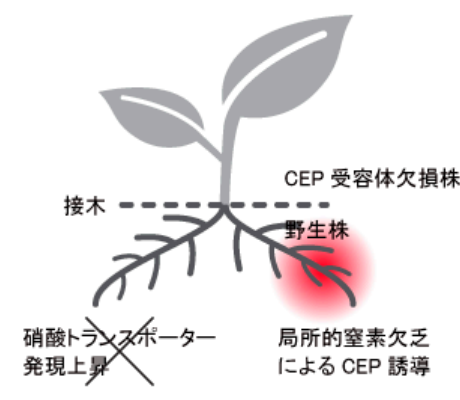

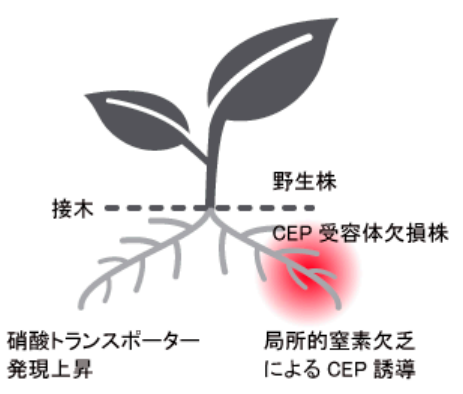

B

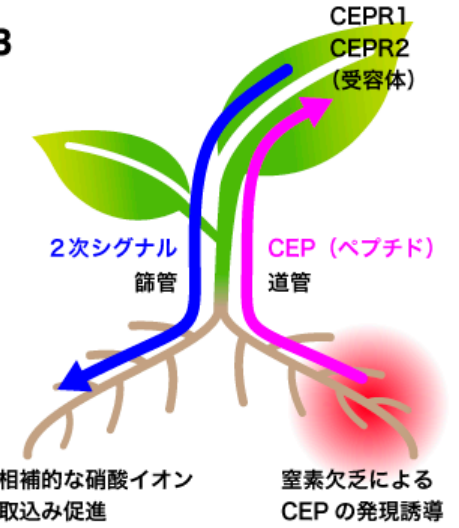

図2＼cjkstart分泌型ペプチドCEPとLRR型受容体CEPRを介した全身的窒素要求シグナリング

(A) CEPの受容部位を示す接木実験。根由来のCEPは地上部のCEP受容体によって認識されることが示された。(B) CEPの 作用モデル。根の一部が窒素欠乏を感知するとCEPが生産され、道管を通って地上部に送られた後、葉の維管束で発現し ている受容体CEPRによって認識される。これが引き金となり、全身に窒素欠乏を伝える未知の二次シグナルが誘導され、 NRT2.1などの硝酸トランスポーター発現量が上昇し、相補的な硝酸取り込みが行なわれる。

欠乏に陥った際にしばしば観察されるため、CEPが窒素 応答に関与している可能性が示唆された。

CEPが窒素応答のどのような過程に関与するか調べ るため、野生型と CEP受容体欠損株の根由来のRNA を比較したマイクロアレイ解析を行なった。その結 果、CEP受容体欠損株の根に抒いては、主要な硝酸人 オン輸送体 (Nitrate Transporter: NRT) であるNRT2.1、 NRT3.1、NRT1.1などの発現量が著しく低下しているこ とが明らかとなった。さらに合成ペプチドを根に与える 実験から、NRT遺伝子群がCEPの制御下にあることが 実際に確かめられた。

これら3つの $N R T$ 遺伝子群は、全身的窒素要求シグナ リング (systemic N-demand signaling)によって制御され ていることが知られている。全身的窒素要求シグナリン グとは、一部の根の周辺に硝酸イオンが不足した場合に、 別の根の硝酸イオン取り込久量を増やして相補する制御 系のことであり、土壤中の硝酸イオンの分布が不均一な 環境で生き抜くために植物が進化させた巧妙なシステム である。しかし、全身的窒素要求シグナリングの分子メ カニズムはよく分かっていなかった。筆者らは、全身的 窒素要求シグナリングのターゲットとして知られていた 他の複数の遺伝子のいずれもが、CEP受容体欠損株で は発現低下していたことや、分泌型ペプチドは組織内を 移行しうることを考慮して、CEPが全身的窒素要求シグ ナリングに関与しているという仮説を立て、その検証を 進めた。

本稿では実験の詳細は省略するが、得られた結果は 以下の通りである。(1) $C E P$ 遺伝子群は、窒素欠乏特異 的に発現誘導された。(2) 1本の植物から出る根を2束に 分けて、それぞれ異なる条件に晒す、スプリットルー 卜培養系 (Split-root culture system) を用いた解析におい て、CEP受容体欠損株では、片側の根を窒素欠乏にし た場合において反対側の根における硝酸イオン輸送体の 発現上昇はみられなかった。すなわち、CEP受容体欠 損株では全身的窒素要求シグナリングが起こらなかっ
た。(3) 窒素が十分に存在する培地上でも、スプリット ルート培養系で片側の根をCEP1処理した場合、反対側 の根においても硝酸イオン輸送体の発現上昇が見られた。 (4) 接木実験から、地上部の CEP受容体による根由来 CEPの認識が、システミックな硝酸イオン輸送体の発 現上昇のために重要であることが示された(図2A)。(5) Nano LC-MS/MS 解析によって、CEPは根から地上部へ 道管を通って移行していることが示された。

以上の結果をまとめると、次のような作用モデルが考 えられる(図2B)。土壤中で根の一部が窒素欠乏を感知す るとCEPファミリーペプチドが生産され、それらが道管 を通って地上部に送られる。地上部に達したCEPは、葉 の維管束で発現している受容体CEPRによって認識され、 全身に窒素欠乏を伝える未知の二次シグナルの生産を誘 導する。この二次シグナルは、技そらく穊管を通って再 び根に移行し、周囲にまだ硝酸イオンが存在している他 の根に働きかけて硝酸イオン輸送体発現量を上昇させる。

\section{おわりに}

これまで、植物は一部の根の周辺に硝酸イオンが欠乏 すると、別の根の硝酸イオン取り込々量を増やすという 応答を示すことまでは知られていたが、そのメカニズム はほとんど明らかにされていなかった。今回の発見に より、根で生産される分泌型ペプチドホルモンCEPを、 葉において受容体CEPRが受け取ることが、システミッ クな窒素要求シグナリングの根幹をなすことが明らかと なった。これは、動物において空腹時に胃で空腹ホルモ ンであるグレリンが生産され、それが迷走神経末端に存 在する受容体で受容されると、その情報が脳に伝達され、 最終的に摂食と成長ホルモン分泌が促進されるしくみに 類似しており、極めて興味深い。すなわち CEPは、植 物における空腹ホルモンであると言えるだろう。今後は、 CEPがCEPRによって認識された後に葉で生産され根に 運ばれると考元られる未知の二次シグナルの解明に興味 が持たれる。 